\title{
PENGARUH PERPUTARAN PIUTANG TERHADAP PROFITABILITAS PADA TOKO MULIA GORDYN
}

\author{
Putri Erisa Harahap, Riandani Rezki Prana, Handri A Sukendro \\ Alumni Sekolah Tinggi Ilmu Manajemen Sukma \\ Program studi Manajemen, Sekolah Tinggi Ilmu Manajemen \\ riandanirezki@gmail.com, handrias19@gmail.com
}

\begin{abstract}
The purpose of this study is to determine the effect of receivable turnover on profitability. The population of this study is the financial statements Store Mulia Gordyn year 2005-2016. This research is a quantitative descriptive research to know the effect of receivable turnover to profitability. The data collection instrument uses direct documentation and observation which is then analyzed using simple linear regression. Data processing using SPSS 20. The result of this research is receivable turnover have positive and significant effect to profitability
\end{abstract}

Keywords: Receivable Turnover, profitability, Mulia Gordyn Store.

\section{PENDAHULUAN}

Tujuan utama berdirinya suatu perusahaan adalah untuk memperoleh laba yang maksimal. Dengan memperoleh laba yang maksimal, maka perusahaan dapat terus beroperasi sesuai dengan perencanaan yang telah dibuat oleh perusahaan dan mencapai tujuan yang diinginkan oleh pemilik perusahaan. Perusahaan dituntut untuk mampu memilih strategi yang tepat sehingga tetap dapat bersaing di pasaran dan dapat mengungguli para pesaingnya, dengan demikian kemampuan perusahaan untuk dapat bertahan ditengah perubahan iklim bisnis yang sering berubah-ubah bisa dijamin dalam waktu yang panjang. Profitabilitas digunakan sebagai tolak ukur berhasil atau tidaknya perusahaan menghasilkan laba serta efisiensi dan efektivitas manajemen dalam mengelola sumberdaya yang dimilikinya. Salah satu cara yang dilakukan perusahaan yaitu dengan melakukan penjualan. Penjualan bisa dilakukan dengan dua cara yaitu penjualan tunai dan penjualan kredit. Perputaran piutang (receivable turnover) menunjukkan berapakali suatu perusahaan melakukan tagihan atas piutangnya dalam suatu periode tertentu. Kebijakan dalam pengumpulan piutang sangat penting dalam pengendalian tingkat perputaran piutang dalam perusahaan. Semakin tinggi perputaran piutang menunjukkan masuknya kas kepada perusahaan berjalan lancar.

Penelitian yang dilakukan oleh Sulaiman (2015) dengan judul pengaruh perputaran piutang terhadap profitabillitas studi empiris pada perusahaan sektor industri dasar dan kimia yang terdaftar di Bursa Efek Indonesia Periode 2010-2013, hasilnya menunjukkan bahwa terdapat pengaruh yang signifikan antara perputaran piutang terhadap profitabilitas. Selain itu hal ini juga diperkuat oleh penelitian yang dilakukan oleh Azhari (2013) tentang pengaruh perputaran piutang terhadap profitabilitas pada PT. Mita Utama Dental yang menyatakan bahwa perputaran piutang memliki pengaruh positif terhadap profitabilitas. Hal tersebut terjadi jika perputaran piutang naik maka profitabilitas juga naik dan jika perputaran profitabilitas turun maka profitabilitas juga akan menurun. Namun hal sebaliknya diungkapkan oleh Suarnami et al (2014) dalam penelitiannya yang berjudul pengaruh perputaran piutang dan periode pengumpulan piutang terhadap profitabilitas pada perusahaan pembiayaan, menyatakan bahwa perputaran piutang tidak berpengaruh signifikan terhadap 
profiabilitas. Hal ini berarti tidak berpengaruh secara langsung dalam upaya mendukung peningkatan profitabilitas. Hal serupa juga dikemukakan oleh Ray dan Mahavidyalaya (2012) dalam jurnalnya yang berjudul evaluating the impact of working capital managements components on corporate profitability: efidance from indian manufacturing firms. Menyatakan adanya hubungan negatif antara manajemen modal termasuk jumlah hari pengumpulan piutang dan siklus konversi kas, rasio hutang dengan profitabilitas perusahaan.

\section{Rumusan Masalah}

Berdasarkan uraian diatas maka penulis merumuskan masalah apakah ada pengaruh perputaran piutang terhadap profitabilitas pada Toko Mulia Gordyn?

\section{Batasan Masalah}

Guna memperjelas arah penelitian, batasan masalah penelitian ini yaitu hanya pada laporan keuangan toko mulia gordyn pada periode 2005-2016. Piutang yang dimaksud dalam penelitian ini adalah piutang dangang. Indikator profitabilitas yang digunakan adalah rasio Net Profit Margin.

\section{Tujuan Penelitian}

Tujuan penelitian ini adalah untuk mengetahui pengaruh perputaran piutang terhadap profitabilitas pada toko mulia gordyn.

\section{METODE PENELITIAN}

\section{Metode Analisis Data}

Metode analisis data yang digunakan dalam penelititan ini adalah metode deskriptif kuantitatif, sedangkan model analisis yang digunakan dalam penelititan ini adalah regresi linier sederhana, dengan model persanaan.

$$
\begin{array}{ll}
\text { Keterangan: } & \mathrm{Y}=\mathrm{a}+\mathrm{bX}+\mathrm{e} \\
\mathrm{Y} & =\text { Profitabilitas } \\
\mathrm{X} & =\text { Perputaran piutang } \\
\mathrm{a} & =\text { Konstanta } \\
\mathrm{b} & =\text { Koefisien regresi } \\
\mathrm{e} & =\text { error of term (variable yang tidak diteliti) }
\end{array}
$$

\section{Kerangka Berpikir}

Pemberian piutang kepada pelanggan sangat penting dalam meningkatkan omzet penjualan perusahaan, jika omzet perusahaan besar maka profit yang didapatkan oleh perusahaan juga besar. namun perusahaan juga harus memperhatikan tingkat perputaran piutangnya untuk kelangsungan operasi perusahaan. Penelitian yang dilakukan oleh Suarnami et al (2014) menunjukkan bahhwa perputaran piutang dan periode pengumpulan piutang berpengaruh positif dan signifikan terhadap profitabilitas.

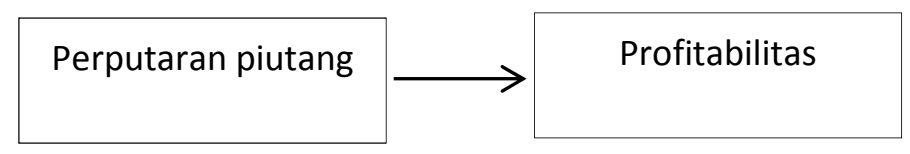

Gambar 1. Kerangka Berpikir 


\section{Hipotesis}

Menurut Yusuf (2014:130) meyatakan bahwa "hipotesis adalah suatu dugaan sementara, suatu tesis sementara yang harus dibuktikan kebenarannya melalui penyelidikan ilmiah".

Formulasi hipotesis penelitian ini adalah:

Jika $t_{\text {hitung }}<t_{\text {tabel }}$ maka $\mathrm{H}_{0}$ diterima, $\mathrm{H}_{1}$ ditolak, artinya secara parsial perputaran piutang tidak berpengaruh terhadap profitabilitas, sedangkan jika $t_{\text {hitung }}>t_{\text {tabel }}$ maka $\mathrm{H}_{0}$ ditolak, $\mathrm{H}_{1}$ diterima, artinya secara parsial perputaran piutang berpengaruh terhadap profitabilitas.

Berdasarkan pengertian diatas maka hipotesis penelitian ini adalah "ada pengaruh perputaran piutang terhadap profitabilitas".

\section{Pengujian Hipotesis}

1. Koefisien Determinasi $\left(R^{2}\right)$

Koefisien determinasi $\left(R^{2}\right)$ pada intinya mengukur seberapa besar kemampuan model dalam menerangkan variabel terikat. Semakin besar nilai koefisien determinasi (mendekati satu), maka dapat dikatakan bahwa pengaruh variabel bebas (X) adalah besar terhadap variabel terikat $(\mathrm{Y})$

2. Uji Parsial (Uji t)

Uji parsial (uji t) bertujuan untuk melihat pengaruh perputara piutang terhadap profitabilitas, dengan kriteria:

1. Jika $t_{\text {hitung }} \leq t_{\text {tabel }}$, maka $H_{0}$ diterima, $H_{1}$ ditolak, artinya secara parsial penelitian ini tidak berpengaruh;

2. Jika $t_{\text {hitung }}>t_{\text {tabel }}$, maka $H_{0}$ ditolak, $H_{1}$ diterima, artinya secara parsial penelitian ini berpengaruh.

\section{HASIL DAN PEMBAHASAN}

\section{Deskripsi Data Variabel Perputaran Profitabilitas}

Piutang atau penjualan kredit merupakan salah satu keputusan investasi yang beresiko untuk meningkatkan profitabilitas perusahaan. Untuk mengetahui perkembangan profitabilitas Toko Mulia Gordyn rasio profitabilitas yang dipakai yaitu Net Profit Margin.

Tabel 1 Perputaran Piutang Toko Mulia Gordyn 2005-2016 ( Dalam Rupiah)

\begin{tabular}{|c|c|c|c|}
\hline Tahun & Laba Bersih & Penjualan & NPM \% \\
\hline 2005 & $1,536,622,016.34$ & $22,657,169,812$ & 0.06782056 \\
\hline 2006 & $2,081,674,003.92$ & $25,544,971,062$ & 0.08149056 \\
\hline 2007 & $3,067,833,994.51$ & $27,576,780,910$ & 0.11124699 \\
\hline 2008 & $3,812,508,371.12$ & $28,977,897,622$ & 0.13156608 \\
\hline 2009 & $3,581,674,003.92$ & $31,995,486,000$ & 0.1119431 \\
\hline 2010 & $3,536,622,016.34$ & $32,445,907,880$ & 0.10900056 \\
\hline 2011 & $3,581,674,003.92$ & $32,005,960,612$ & 0.11190647 \\
\hline 2012 & $3,367,833,994.51$ & $31,988,366,275$ & 0.10528309 \\
\hline 2013 & $4,812,508,371.12$ & $33,093,600,827$ & 0.14542112 \\
\hline 2014 & $5,795,811,201.04$ & $34,404,183,217$ & 0.1684624 \\
\hline 2015 & $3,573,994,760.74$ & $32,265,013,568$ & 0.11076998 \\
\hline 2016 & $5,467,680,657.00$ & $35,594,910,026$ & 0.1536085 \\
\hline
\end{tabular}


Kemampuan Toko Mulia Gordyn dalam menghasilkan laba bersih dari setiap rupiah pendapatan hasil penjualan pada kurun waktu dua belas tahun secara rata-rata sebesar $11,7 \%$ dan terus mengalami fluktuasi.

Dari tabel diatas dapat disimpulkan bahwa kemampuan Toko Mulia Gordyn dalam menghasilkan laba atau Profitabilitas cukup bagus. Hal ini dapat dilihat dari Profitabilitas yang dihasilkan Toko Mulia Gordyn setiap tahunnya mengalami fluktuatif. Keadaan ini menggambarkan bahwa kemampuan Toko Mulia Gordyn dalam menghasilkan laba cukup baik.

\section{Uji Regresi Linier Sederhana}

Untuk mengetahui pengaruh perputaran piutang terhadap profitabilitas, maka digunakan uji regeresi linier sederhana. Berikut adalah tabel hasil pengujian regresi pada masing-masing variabel

Coefficients $^{a}$

\begin{tabular}{|c|c|c|c|c|c|}
\hline \multirow[t]{2}{*}{ Model } & \multicolumn{2}{|c|}{ Unstandardized Coefficients } & \multirow{2}{*}{$\begin{array}{c}\text { Standardized } \\
\text { Coefficients } \\
\text { Beta }\end{array}$} & \multirow[t]{2}{*}{$\mathrm{t}$} & \multirow[t]{2}{*}{ Sig. } \\
\hline & B & Std. Error & & & \\
\hline (Constant) & 2.755 & 2.482 & & 1.110 & .293 \\
\hline Perputaran Piutang & 1.543 & .415 & .761 & 3.713 & .004 \\
\hline
\end{tabular}

a. Dependent Variable: Profitabilitas berikut :

Berdasarkan hasil pengujian diatas, maka diperoleh persamaan regresi sebagai

$$
\mathrm{Y}=2,755+1,543 \mathrm{X}
$$

Persamaan regresi diatas dapat diartikan sebagai berikut:

1. Nilai konstanta (a) sebesar 2,755. Artinya adalah apabila Perputaran Piutang diasumsikan nol (0), maka NPM bernilai 2,755

2. Nilai koefisien regresi variabel Perputaran Piutang 1,543. Artinya adalah apabila Perputaran Piutang meningkat sebesar 1 \% maka NPM akan naik sebesar 1,543\%.

\section{Pengujian Hipotesis}

a. Koefisien Determinasi

\begin{tabular}{|l|r|r|r|r|}
\hline \multicolumn{6}{|c|}{ Model } & \multicolumn{1}{|c|}{ R } & \multicolumn{1}{|c|}{ R Square } & Adjusted R Square & \multicolumn{1}{c|}{$\begin{array}{c}\text { Std. Error of the } \\
\text { Estimate }\end{array}$} \\
\hline 1 & $.761^{\mathrm{a}}$ & .580 & .538 & 1.94664 \\
\hline
\end{tabular}

a. Predictors: (Constant), Perputaran Piutang

Berdasarkan tabel diatas diperoleh nilai $\mathrm{R}^{2}$ sebesar 0,580. Artinya adalah bahwa sumbangan pengaruh variabel independen (Perputaran Piutang) terhadap variabel dependen profitabilitas (NPM) adalah sebesar 58\%, sedangkan sisanya sebesar $42 \%$ dipengaruhi oleh variabel lain yang tidak dijelaskan dalam model penelitian ini. 


\begin{tabular}{|c|c|c|c|c|c|}
\hline \multirow[t]{2}{*}{ Model } & \multicolumn{2}{|c|}{ Unstandardized Coefficients } & \multirow{2}{*}{$\begin{array}{c}\text { Standardized } \\
\text { Coefficients } \\
\text { Beta }\end{array}$} & \multirow[t]{2}{*}{$\mathrm{t}$} & \multirow[t]{2}{*}{ Sig. } \\
\hline & $B$ & Std. Error & & & \\
\hline (Constant) & 2.755 & 2.482 & & 1.110 & .293 \\
\hline Perputaran Piutang & 1.543 & .415 & .761 & 3.713 & .004 \\
\hline
\end{tabular}

a. Dependent Variable: Profitabilitas

Berdasarkan tabel diatas dapat diketahui bahwa :

Nilai $t_{\text {hitung }}>t_{\text {tabel }}(3,713>2,228)$ dan signifikan $0,004<$ dari nilai alpha $(0,05)$, maka H0 ditolak dan $\mathrm{H} 1$ diterima, dengan demikian secara parisal perputaran piutang berpengaruh terhadap profitabilitas.

\section{Pembahasan}

Hasil pengujian hipotesis menunjukkan bahwa perputaran piutang secara parsial berpengaruh dan signifikan terhadap profitabilitas, hal ini dibuktikan dengan nilai $t_{\text {hitung }}>$ $t_{\text {tabel }}(3,713>2,228)$ dan signifikan $0,004<$ dari nilai alpha $(0,05)$.

Berdasarkan uji koefisien determinasi dapat disimpulkan bahwa perputaran piutang mampu menjelaskan variasi yang terjadi pada profitabilitas, hal ini ditunjukkan dengan nilai koefisien determinasi $\left(R^{2}\right)$ sebesar 58\% sedangkan sisanya sebesar $42 \%$ dipengaruhi oleh variabel lain yang tidak dijelaskan dalam model penelitian ini.

\section{Kesimpulan}

Berdasarkan hasil penelitian dan pembahasan mengenai pengaruh perputaran piutang terhadap profitabilitas pada Toko Mulia Gordyn, maka penulis dapat menyimpulkan sebagai berikut :

1. Perputaran piutang yang terjadi pada Toko Mulia Gordyn dalam kurun waktu 12 tahun terakhir yaitu dari tahun 2005-2016 cukup baik, hal ini terbukti dari perputaran piutang perusahaan cukup tinggi. Hal ini ditunjukkan dengan rata-rata perputaran piutangnya sebesar 5,82 kali selama 12 tahun.

2. Berdasarkan data-data yang diperoleh juga dapat diketahui bahwa kemampuan untuk mendapatkan laba atau profitabilitas pada Toko Mulia Gordyn dalam kurun waktu tujuh tahun terakhir yaitu dari tahun 205-2016 juga cukup baik, hal ini ditunjukkan oleh laba atau profit yang dimiliki rata-rata $11,7 \%$. 


\section{REFERENCES}

Azhari,Ulpha Lisni. (2013). Pengaruh Perputaran Piutang Terhadap Profitabilitas pada PT. Mita Utama Dental. Universitas Pendidikan Indonesia.

Cece. (2003). Analisis Hubungan Perencanaan Strategi Aliansi PDAM Tirtanadi-PT. Telekominikasi Divre I Terhadap Peningkatan Kualitas Pelayanan Pelanggan PDAM Tirtanadi... Universitas Sumatera Utara.

Dinamika, S. G. (2018). Gemstone Fever Hits Jakarta: A Lexical Meaning Analysis.

Dinamika, S. G., \& Sari, W. V. (2015). Applied Error Analysis of Comparative Degree Sentence Construction of Students in STIM Sukma Medan. Asian EFL Journal, 5, 112-119.

Dinamika, Soraya Grabiella (2014) THE EFFECT OF USING COLLABORATIVE STRATEGIC READING ON STUDENTS' ACHIEVEMENT IN READING NARRATIVE TEXT. Undergraduate thesis, UNIMED

Fahmi, I. (2014). Manajemen Keuangan Perusahaan dan Pasar Modal (1st ed.). Jakarta: Mitra Wacana Media.

Fahmi, I. (2015). Pengantar Manajemen Keuangan Teori dan Soal Jawab. (M. A. Djalil, Ed.). Bandung: Alfabeta.

Fathimah, V. (2017). Pengaruh Perkembangan Jumlah Tabungan, Deposito dan Bagi Hasil terhadap Jumlah Pembiayaan yang Diberikan oleh Perbankan Syariah di Sumatera Utara. Jurnal Ilman, 5(1), 41-52.

Hery. (2013). Akuntansi Keuangan Menengah. Jakarta: Buku Seru.

Hidayat, R. (2009). Penerapan Sistem lnformasi Manajemen sebagai Alat Pelaksanaan Sistem Administrasi Akademik. JURIDIKTI: Jurnal Ilmiah Pendidikan Tinggi, 2(2), 56-59.

Hidayat, R. (2010). Analisis Tingkat Penggunaan Internet Dikalangan Mahasiswa dan Hubungannya dalam Peningkatan Nilai Akademik (Studi Kasus pada Mahasiswa di Kota Medan). Jurnal Mediasi, 2(2), 55-63.

Mahavidyalaya, S. S. (2012). Evaluating the Impact of Working Capital Management Components on Corporate Profitability : Evidence from Indian Manufacturing Firms, 2(3), 127-136.

Nasution, W. A. (2009). Pengaruh kepuasan kerja karyawan terhadap intensi turnover pada call center Telkomsel di Medan. Jurnal Mandiri, 4(1), 1-11.

Nasution, W. A. (2013). Pengaruh kompensasi dan lingkungan kerja terhadap kepuasan kerja karyawan pada PT. Karya Deli Stelindo Medan. Jurnal Manajemen Bisnis STIE IBBI, 20(2), 177.

Nasutiona, L. K., Fahrurb, M., Christine, Imaduddind, \& Wardayani. (2017). The Calculation of Cost of Goods Sold "Gayo Arabica Coffee from Takengon" with Variable Costing Method. Journal Online Jaringan COT POLIPD (JOJAPS), 10, 82-87.

Ningratri, Y. A. (2017). Analisis Pengaruh Strategi Bauran Pemasaran Jasa (3P) terhadap Keputusan Mahasiswa Memilih STIM Sukma Medan. Riset \& Ejurnal Manajemen Informatika, 3(1), 50-56.

Nurlinda, \& Wardayani. (2014). Pengaruh Partisipasi Penyusunan Anggaran Dan Penggunaan Instrumen Manajemen Terhadap Kinerja Pengelolaan Dana Bantuan Global Fund Komponen Aids Pada Kementerian Kesehatan Ri. Jurnal Ilman, 1(1), 23-35. 
Pena, T. P. (2015). Kamus Terbaru Ekonomi dan Bisnis. (Tim Prima Pena, Ed.) (1st ed.). Surabaya: Gitamedia Press.

Prana, R. R. (2016). Analisis Faktor-faktor yang Mempengaruhi Pendapatan Asli Daerah (PAD) Kota Tebing Tinggi. Jurnal IIman, 4(1), 74-86.

Raidani, Pertiwi, L. S., Wulandari, D. Y., \& Zuhri. (2016). Tobit and Interval Censored Regression Model. Global Journal of Pure and Applied Mathematics, 12(1), 981-994.

Safriandi, F., Pertiwi, L. S., Fitriani, A., \& Zuhri. (2016). Truncated Regression Model and Nonparametric Estimation for Gifted and Talented Education Program. Global Journal of Pure and Applied Mathematics, 12(1), 995-1002.

Sinaga, S., Pertiwi, L. S., Ardian, T., \& Zuhri. (2016). Inventory Simulation Optimization Under Non Stationary Demand. International Journal of Applied Engineering Research, 11(1), 524-529.

Sinuhaji, E. (2010). PENERAPAN LAYANAN UNGGUL DALAM PEMASARAN PRODUK BANK. Jurnal Mediasi, 2(1).

Sinuhaji, E. (2013). PENGARUH BUDAYA ORGANISASI TERHADAP KEPUASAN KERJA KARYAWAN PADA JASA PERHOTELAN (Studi Kasus di Garuda Plaza Hotel Medan). Bisnis Administrasi, 2(1), 2537.

Sinuhaji, E. (2014). Pengaruh Kepribadian, Kemampuan Kerja dan Motivasi Kerja terhadap Kinerja SDM Outsourcing pada PT. Catur Karya Sentosa Medan. Jurnal Ilman, 1(1), 11-22.

Sjahrial, D. (2014). Manajemen Keuangan Lanjutan (1st ed.). Jakarta: Mitra Wacana Media.

Suarnami, L. K., Suwendra, I. W., \& Cipta, W. (2014). Pengaruh Perputaran Piutang dan Periode Pengumpulan Piutang Terhadap Profitabilitas Pada Perusahaan Pembiayaan eJournal Bisma Universitas Pendidikan Ganesha, 2.

Sujarweni, V. W. (2015). Metodologi Penelitian Bisnis dan Ekonomi. Yogyakarta: Pustakabarupress.

Sukendro, H. A. (2012). Pengaruh Citra Merek dan Kualitas Pelayanan terhadap Kepuasan Jama'ah pada Kelompok Bimbingan Ibadah Haji (KBIH) Indosat Medan. Universitas Terbuka.

Sulaiman, U. F. (2015). Pengaruh Perputaran Piutang Yerhadap Profitabillitas Studi Empiris Pada Perusahaan Sektor Industri Dasar dan Kimia yang Terdaftar di Bursa Efek Indonesia Periode 2010-2013. Universitas Widyatama.

Supriyanto, \& Hidayat, R. (2010). Rancangan Sistem Informasi Administrasi Akademik berbasis Komputer. JURIDIKTI: Jurnal IImiah Pendidikan Tinggi, 3(3), 147-157.

Utari, Dewi, Purwanti, Ari, Prawironegoro, D. (2014). Manajemen Keuangan. Jakarta: Mitra Wacana Media.

Wahyuni, D. S., \& Wardayani. (2016). Analisis Return on Asset, Current Ratio dan Debt Ratio dalam Menilai Kinerja Keuangan pada PT . Pelabuhan Indonesia I (Persero) cabang Belawan. Jurnal Ilman, 4(1), 59-73.

Widjanarko, B. (2015). PENGARUH PEMERIAN KOMPENSASI DAN KOMUNIKASI TERHADAP SEMANGAT KERJA KARYAWAN PADA BUMI KARYA TAMA INSURANCE CABANG MEDAN. Jurnal Research Sains, 1(2), 130-152.

Winata, E. (2015). Pengaruh Disiplin Kerja dan Budaya Kerja terhadap Semangat Kerja Karyawan pada PT. Mayasari Binangun Medan. Research Sains, 1(2), 100-117.

Winata, E. (2015). Pengaruh Pemberian Kompensasi dan Penilaian Prestasi Kerja terhadap Produktivitas kerja Karyawan pada PT. Askrindo cabang Medan. Jurnal Dunia Ilmu, 1(2). 
Winata, E. (2017). ANALISA PERAMALAN PENJUALAN DAN PROMOSI PENJUALAN TERHADAP PENINGKATAN VOLUME PENJUALAN PADA PT. CAKRA ANUGERAH ARTA ALUMINDO MEDAN. Research Sains, 3(1).

Yusuf, M. (2014). Metode Penelitian Kuantitatif,Kualitatif,dan Penelitian Gabungan (1st ed.). Jakarta: Prenadamedia Group. 